Article

\title{
Effect of Urban Development in Risk of Floods in Veracruz, Mexico
}

\author{
Emmanuel Zúñiga ${ }^{1, *(\mathbb{D})}$, Víctor Magaña ${ }^{2}$ and Violeta Piña ${ }^{3}$ \\ 1 CONACYT-Instituto de Geografía, Universidad Nacional Autónoma de México, \\ Circuito de la Investigación Científica, Ciudad Universitaria, Ciudad de México 04510, Mexico \\ 2 Instituto de Geografía, Universidad Nacional Autónoma de México, Circuito de la Investigación Científica, \\ Ciudad Universitaria, Ciudad de México 04510, Mexico; victormr@unam.mx \\ 3 Posgrado en Ciencias de la Tierra, Universidad Nacional Autónoma de México, \\ Circuito de la Investigación Científica, Ciudad Universitaria, Ciudad de México 04510, Mexico; \\ mavipigo@outlook.es \\ * Correspondence: ezuniga@igg.unam.mx
}

Received: 21 August 2020; Accepted: 2 October 2020; Published: 9 October 2020

check for updates

\begin{abstract}
Urban floods have adverse effects on the population and the economy, and they are increasing in frequency and magnitude. The State of Veracruz is the region of Mexico with the highest number of disasters, more than $50 \%$ of the total number nationwide, in the 1970-2015 period. During the 1990s, disasters in this region increased from 5 to 10 events per year, mostly in relation to intense rains and floods. This study analyzes the factors that increase the risk of urban floods in the regions: (i) the Pánuco River, (ii) the Papaloapan River, and (iii) the Coatzacoalcos River regions, combining hazard data and estimates of vulnerability factors. The 95th percentile of daily precipitation (P95) is used as a threshold of heavy rain, i.e., the natural hazard. Vulnerability is estimated in terms of the percentage of natural vegetation loss due to changes in land cover and land use in the hydrological basins and the expansion of the urban areas in the regions under study. The risk of flood was compared with records of flood events focusing on the low-frequency variations of risks and disaster activity. The trends in urban flood activity are related to the loss of natural vegetation and deterioration of the basins leading to a loss of infiltration, i.e., larger runoffs. Even when the intensity of precipitation in recent decades remains without clear trends, or shows negative tendencies in the number of intense events, the number of floods is higher mostly because of the deterioration of hydrologic basins. Therefore, the risk of flooding in the state of Veracruz is mainly related to environmental factors that result in vulnerability rather than changes in the trends of extreme precipitation activity. This result means that disaster risk reduction actions should be mainly related to rehabilitation of the basins.
\end{abstract}

Keywords: flood risk; vulnerability; hazard; urban climate; land use change

\section{Introduction}

During the 1990-2020 period, more than 50\% of the disasters registered worldwide were related to floods [1-5]. Urban floods are one of the most important hydrometeorological risks faced by urban areas [6-9] and their impacts affect a large percentage of the population and the economic activities given the tendency for people to live in cities [10-14]. Various studies [10,15-21] consider that the increase in the frequency of intense storms is directly responsible for the occurrence of more urban floods. However, concentrating only on the effect of the meteorological hazards [11,22,23] would reduce the problem to a "naturalistic" focus on natural disasters. It is clear now that negative impacts of hazardous meteorological events should be examined as a risk problem, in which vulnerability also plays a key role. Urban floods are an example of how the development scheme of some of large cities 
largely determines the increasing number of floods by modifying the characteristics of the hydrological basins [24]. The adverse effect of land use change (LUC) associated with urban growth, as well as agricultural and livestock activities, has been examined in a number of studies. Some suggest that LUC have a minor impact on the occurrence of flooding $[25,26]$ and that the occurrence of this type of disaster is mainly related to changes in the precipitation patterns. Other emphasize the importance of LUC on the rain-runoff process of hydrological basins, increasing the vulnerability to intense rains and the risk of flooding in urban areas [27-30]. Therefore, in recent studies, the evaluation and quantification of the impacts of LUC in risk dynamics has become not only a matter of study, but a necessity to characterize and manage the current and future risk of floods in view of several adaptation proposals to climate change [29,31-35].

Worldwide, the relationship between urban expansion and the increase in the number and magnitude of urban floods has been documented as an expression of the impacts of an intensified climate change process [36-42]. However, only a few studies report the importance of higher vulnerability of cities as they grow and become more exposed to intense meteorological phenomena. The urbanization of hydrological basins responds to the need for greater public space, for the development of economic and social activities [6,11,43,44]. In some countries like Mexico, urbanization and LUC frequently grow even faster than the population itself, in a development model that substitutes natural vegetation for waterproof materials that increase runoff $[24,45,46]$ and reduces infiltration. This development model, along with insufficient drainage infrastructure, make cities more vulnerable to intense rains, particularly when they are located in the lower parts of basins where some ecosystem services of regulation have diminished significantly. In various parts of the world, such urban model results in greater vulnerability and risk of floods, with negative effects on the population [6,11,41,42,47-49].

The economic, social, and environmental cost of urban floods in Mexico is continuously growing $[24,45,46,50-52]$ and requires special attention with respect to civil protection policies. Between 1970 and 2015, floods have had negative effects in at least 65\% of all municipalities in Mexico [53-55], but around $60 \%$ of them correspond to events along the coastal regions, particularly in states adjacent to of the Gulf of Mexico and the Pacific Ocean [53-59]. This is mainly related to the intensity of rains, but also to the level of deterioration of the natural landscapes [45]. The state of Veracruz, between the Sierra Madre and the Gulf of Mexico, is one of the rainiest regions of Mexico. For instance, in September, the monthly precipitation may be around $600 \mathrm{~mm} / \mathrm{month}$ in some parts of the state (Figure 1a). Extreme daily precipitation events may be more than 200/day, and consequently, the hazard is large. However, the number of floods in Veracruz has grown in recent decades, after the 1990s, affecting rural and urban areas.

The population of Veracruz has quadrupled since the 1950s, reaching more than eight million people in recent years, living in the main cities of northern (Panuco River), central (Papaloapan River), and southern (Coatzacoalcos River) regions of Veracruz (Figure 1b). The rapid landscape transformations since the second half of the 20th century [50] have affected around 97\% of their territory, transforming tropical forests, mangroves, and grasslands to urban settlements with roads, but mainly to agricultural and cattle ranching territories [60]. The impact of such LUC in the hydrological basins of the Panuco, Papaloapan, and Coatzacoalcos rivers have been significant and constitute interesting case studies to analyze why the state of Veracruz has suffered the effects of more natural disasters at a large cost that has required large amounts of financial assistance to recover (http://www.e-veracruz.mx/ nota/2017-08-07/ecologia/cambio-de-uso-de-suelo-dana-el-97-de-la-cobertura-vegetal-de-veracruz).

Establishing the importance of the hazard and vulnerability, as in the increasing risk of floods, may determine the type of action for disaster risk reduction. Therefore, the main objective of the present study is to estimate the importance of vulnerability factors related to land use changes, and the significance of intense precipitation activity, as elements that have increased the number of floods particularly in urban environments. For this purpose, case studies in three regions of Veracruz are developed to determine the importance of land use changes as a factor that increases the vulnerability of cities located downstream. 


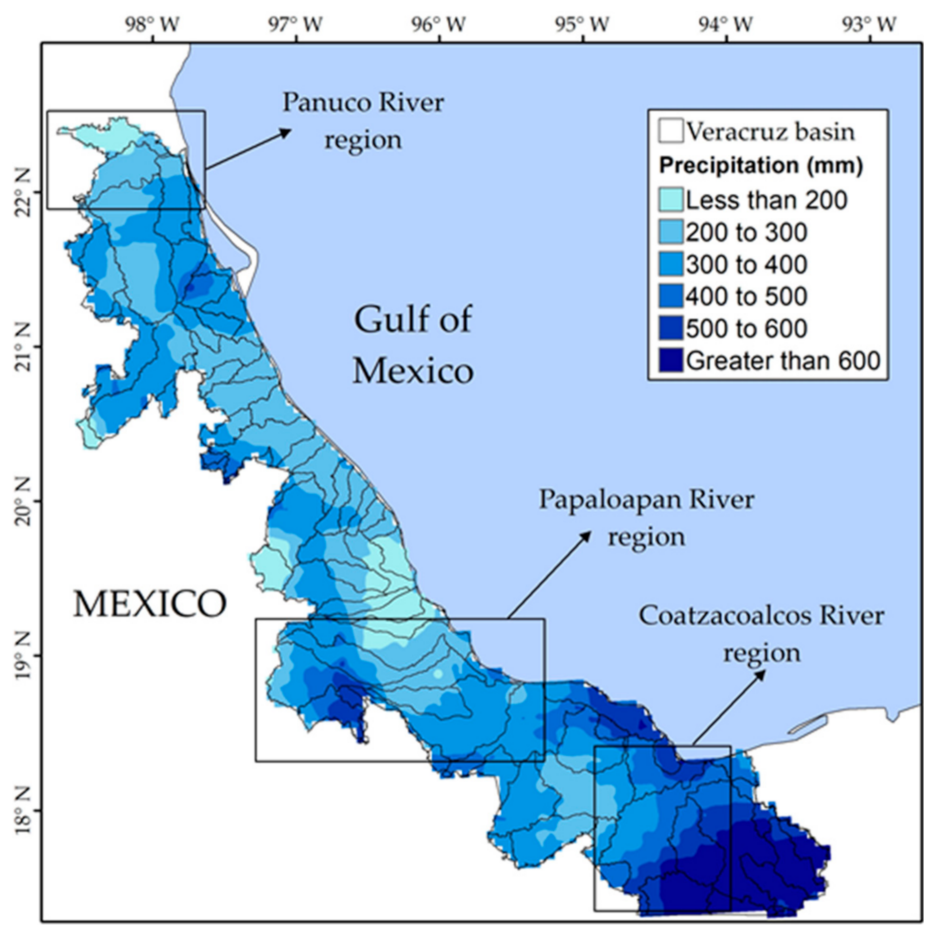

(a)

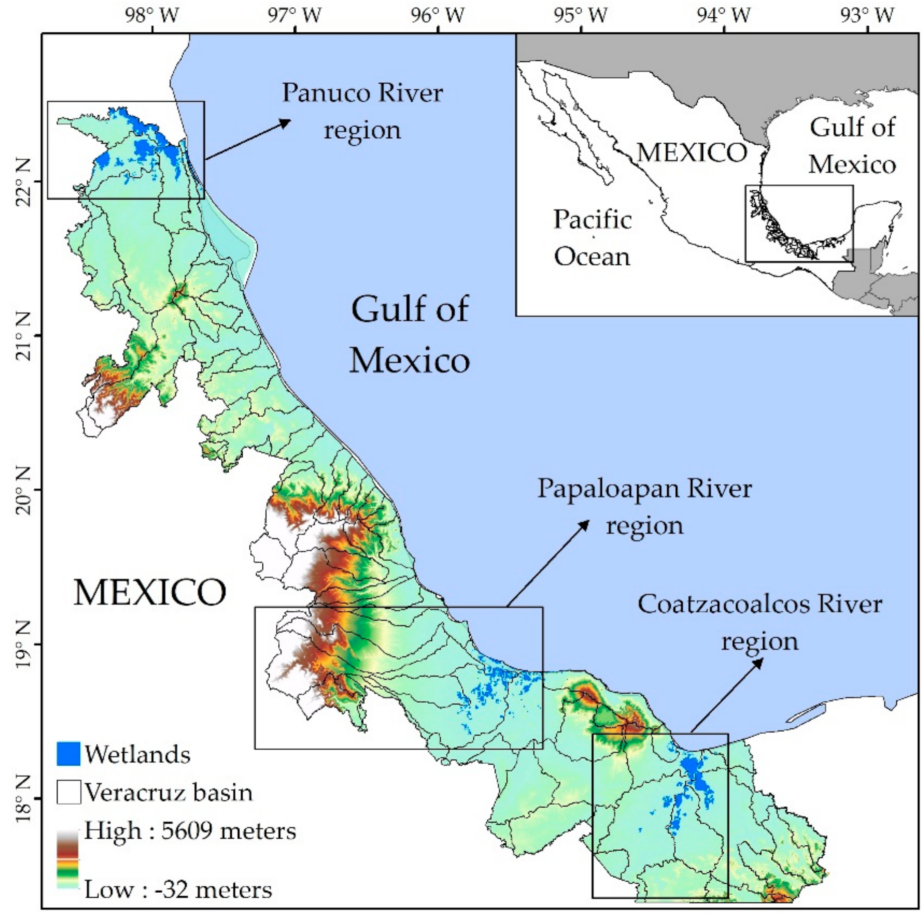

(b)

Figure 1. (a) Spatial pattern of mean September precipitation in southern central Mexico. (Data source: IRI - CHIRPS); (b) Location of the State of Veracruz and study regions. Spatial distribution of hydrological basins and wetlands.

\section{Data and Methodology}

In order to analyze the dynamics of the risk of urban floods in the (i) Pánuco River (northern region), (ii) Papaloapan River (central region), and (iii) Coatzacoalcos River (southern region), it is necessary to characterize the increase in hazard of intense rains, and the evolution of vulnerability in relation to the urban expansion and the land use changes in the region of interest. 
The data used to analyze the frequency of urban floods were obtained from the National Center for Disaster Prevention (CENAPRED) in Mexico [53], the National Disaster Fund-Mexico [55], and the Disaster Inventory known as Desinventar [54]. The information for the 1970-2019 period is processed and analyzed: (i) to eliminate suspicious data (e.g., error in relation to the number of flood events per month), (ii) to standardize the databases, (iii) to eliminate duplicated reports, and (iv) to generate data in an adequate format for geographical information system (GIS) processing.

To establish a threshold of hazard in relation to heavy rains and to the frequency of urban floods, meteorological information for the days with precipitation that resulted in floods was examined. For the period of study, there are 137 flood events in the study regions. Meteorological data, i.e., daily precipitation data, were obtained from 15 weather stations, 5 in each of the three regions, reported by the National Meteorological Service of Mexico [61]. The weather stations selection for the analyses, was based on the following criteria were considered: i) the proximity of the station to urban areas with flood reports, ii) the representativeness of the station within the hydrological basin, and iii) the completeness of daily precipitation data, particularly during the rainy season. Daily rainfall data were analyzed and compared with the flood records in order to obtain rainfall values that may be considered a natural hazard. The 95th percentile of daily precipitation (P95) was an adequate reference to describe the natural hazard. Therefore, the temporal evolution of P95 in five years periods was used to assess changes in the natural hazard activity for urban floods.

The vulnerability associated with changes in land use generates regional changes that can limit or enhance runoff and infiltration and, consequently, constitute a dynamic factor of vulnerability and the risk of urban floods. The vulnerability, expressed as the loss of natural vegetation, is obtained as a percentage of the original values in 1970. Data on the percentage of change of the natural vegetation and on land use was obtained from the National Institute of Geography, Statistics, and Information (INEGI) [62] for the periods: 1970, 1992, 2002, 2004, 2012, and 2016.

The risk of flood is estimated using standardized values of vulnerability and the hazard, in order to obtain a risk of flood index between 0 and 1 , which is a function of space and time for the domains of interest (1). The value 0 corresponds to a "very low" risk, while 1 represents a "very high" risk of flood. The 1970-2015 period of analysis was subdivided into nine 5-year periods for the estimates of hazard, vulnerability and risk of flood. The estimates of risk, hazard, and vulnerability are analyzed and compared with information on the frequency of disasters in order to provide a measure of the skill of the risk model given by:

$$
\mathrm{R}=\mathrm{H} \times \mathrm{V}
$$

where:

$\mathrm{R}=$ risk

$\mathrm{H}=$ hazard

$\mathrm{V}=$ vulnerability

The normalized values of the vulnerability, hazard and risk factors were obtained as:

$$
\mathbf{X}^{\prime}=\frac{(\mathbf{X}-\mathbf{X} \min )}{(\mathbf{X} \max -\mathbf{X} \min )}
$$

where

$\mathbf{X}^{\prime}=$ standardized factor

$\mathbf{X}=$ value of the sample to standardize

$\mathbf{X m i n} ; \mathbf{X m a x}=$ minimum and maximum values of the series 


\section{Results}

\subsection{Trends in the Number of Floods}

The number of floods in Veracruz has had a positive trend since the 1970s, which appears to be related to the land use changes, and increased exposition due to urban growth. The urban area between the 1970s and the 1990 increased by almost 1000\% (Figure 2). The number of reports of floods remained relatively constant between 1970 and 1990, with around five events per year. After the 1990s, land use changes in the basin and the urban expansion increased, just like the number of flood reports in the state, reaching around 25-30 events in certain years, with a relative minimum in flood activity by the mid-1990s. Urban growth accelerated again after the early 2000s. Since then, the number of flood reports has remained high (more than 10 per year). The number of municipalities affected by floods changed from around 30 between 1970 and 1990, to around 210 between 2005 and 2014, just as the urbanized zoned expanded to new regions [53-55].

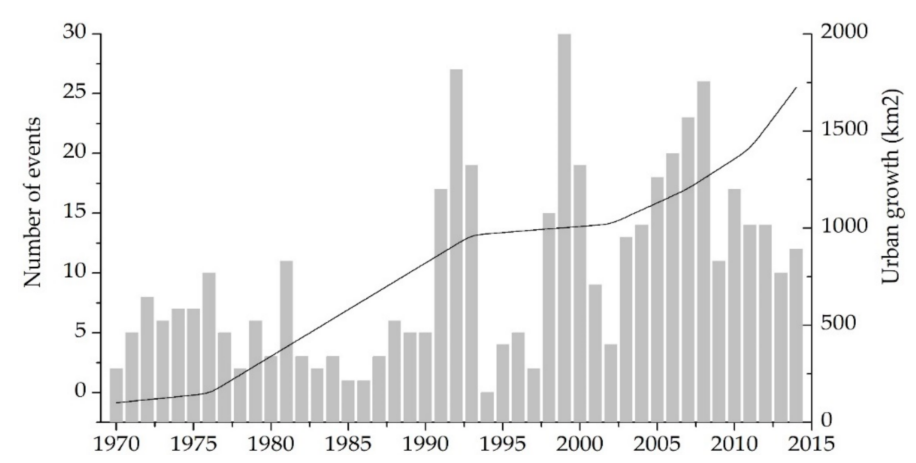

Figure 2. Number of flood events reported in Veracruz (light gray bar) between 1970 and 2015. Urban area (solid black line) for the same period. Source: CENAPRED (1989-2019), FONDEN (2000-2010), DesInventar (1970-2015) and INEGI (1970-2015).

Floods in Veracruz occur mainly during the summer months (May-October), with more than $80 \%$ of all disasters due to intense precipitation of more than $30 \mathrm{~mm} /$ day during this time of the year [63,64]. From November to April, urban floods may occur and are also related to precipitation produced by the so-called "Nortes" [64]. Various studies have proposed that the increased number of floods during the last 20 years is mainly the result of the loss of ecological services (regulation of the hydrological cycle) in the basin, mainly due to deforestation [24]. The intense and rapid convective storms that occur in summer, produce saturation of the soils and greater runoff. During the second half of the rainy season, which corresponds to the month of September, is when this condition generates the maximum number of floods (Figure 3).

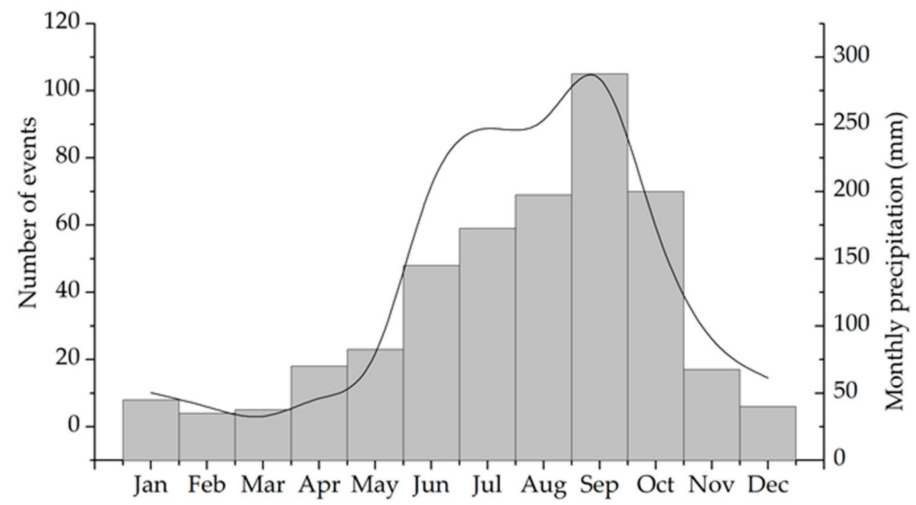

Figure 3. Number of flood events in Veracruz (black line) and average monthly precipitation (gray bars) for the period 1970-2016. 


\subsection{Hazard}

Intense rains in Veracruz occur mainly due to orographic effects, when the trade winds transporting atmospheric moisture interact with the Sierra mountains and results in intense rainfall that generates abundant runoff to the coast of Veracruz. Precipitation events may be considered a natural hazard when they are stronger than the $95 \%$ percentiles of daily precipitation, which for the area of interest are between 15 and $35 \mathrm{~mm} /$ day (Table 1). However, not all extreme precipitation events of this magnitude or stronger result in urban floods. Around $85 \%$ of the rainfall events equal or larger than the P95 resulted in floods. On the other hand, $15 \%$ of these disasters occurred with rains whose intensity was less than the P95. Convective activity in the southern part of Veracruz (Coatzacoalcos) tends to be stronger than in the northern part (Panuco). In Coatzacoalcos and Papaloapan, the yearly number of intense precipitation events ( $p c p>20 \mathrm{~mm} /$ day) is at least twice as large as in Panuco. However, the number of flood events tends to be similar. This is because the vulnerability context is contrasting and constitutes an important modulator of risk. Therefore, hazard activity may explain part of the disaster activity, but the complete risk evaluation, including vulnerability, should explain a larger percentage of floods.

Table 1. Values of P95 (mm/day) for three different periods for the three regions under analysis.

\begin{tabular}{cccc}
\hline Region/Period & $\mathbf{1 9 7 0 - 1 9 9 0}$ & $\mathbf{1 9 9 1 - 2 0 0 0}$ & $\mathbf{2 0 0 0 - 2 0 1 5}$ \\
\hline Panuco basin & 16.3 & 9.9 & 15.1 \\
Papaloapan basin & 33.07 & 31.93 & 31.92 \\
Coatzacoalcos basin & 36.61 & 33.74 & 34.44 \\
\hline
\end{tabular}

The intensity of precipitation has not significantly changed in recent decades, particularly when reference is made to extreme precipitation events. Moreover, the P95 for the region tends to be lower than in the early part of the analysis period (Table 1). Events with rains of $20 \mathrm{~mm} /$ day or more are the same or less frequent than in the past (Figure 4) and cannot explain the increase in the number of floods in Veracruz. In other words, it is not the hazard but the vulnerability to intense rains in the region that acts as a low frequency modulator for the trends in disaster activity. The extreme precipitation event activity better explains the interannual variations in natural disasters.

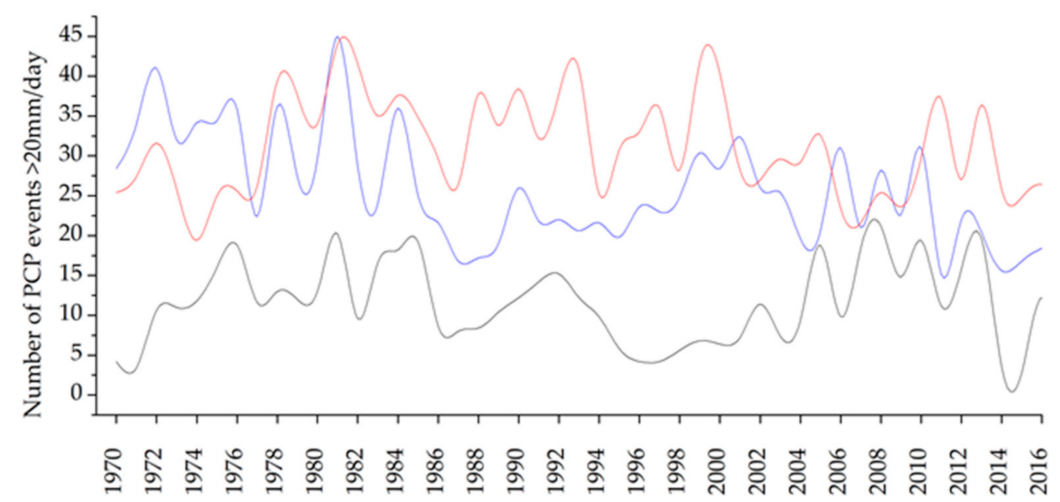

Figure 4. Number of yearly precipitation events above $20 \mathrm{~mm} /$ day for the Panuco (black line), Papaloapan (blue line), and Coatzacoalcos (red line) basins for the period 1970-2015.

\subsection{Vulnerability}

Vulnerability has become an important subject of study to examine the evolution of disasters. However, there is no universally accepted method to determine and quantify vulnerability [65]. One of the most common approaches for the characterization of vulnerability is the use of indicators related to the vulnerability factors $[24,65]$. The multifactorial and dynamical character of vulnerability requires data that provide information in space and in time, in order to determine how it evolves 
and modulates the risk of disasters. In the present analysis, it is the condition of the hydrological basin what may determine de characteristics of runoffs and how they have evolved in time to induce a larger number of floods. In the Veracruz region, basins have been significantly affected due to land use changes for agricultural and cattle ranching activities, increasing the runoff coefficient and reducing ecosystem services.

In recent decades, vulnerability associated with land use changes has resulted in significant losses of natural vegetation and the loss of ecosystem services of infiltration. More than $60 \%$ of the hydrological basins of the State of Veracruz present some degree of degradation due to the transition from tropical forests to other landscapes (Figure 5). In the regions under analysis, the level of degradation is of around 57\% (Panuco), 44.5\% (Papaloapan), and 24.5\% (Coatzacoalcos), i.e., the land use condition observed between 1976 and 2016 has been altered more significantly for the northern region of Veracruz. This makes the Panuco region more vulnerable to intense rains than the central and southern parts of the state. The reduction in the infiltration capacity in the basin and increasing runoff and chances of overflow in the rivers increases the probabilities of floods. So, even when the hazard in northern Veracruz is not as large as in the other regions, its vulnerability is larger, and consequently, the risk of floods may be as large as in the other regions. The loss of forest cover can increase runoff in hydrological basins by between $30 \%$ and $45 \%$ when agricultural soils substitute forests and up to $50 \%$ when urban soils become the new land use in a previously forested region. Therefore, the study regions could be associated with high vulnerability (Pánuco), "moderate vulnerability" (Papaloapan) and "low vulnerability" (Coatzacoalcos).

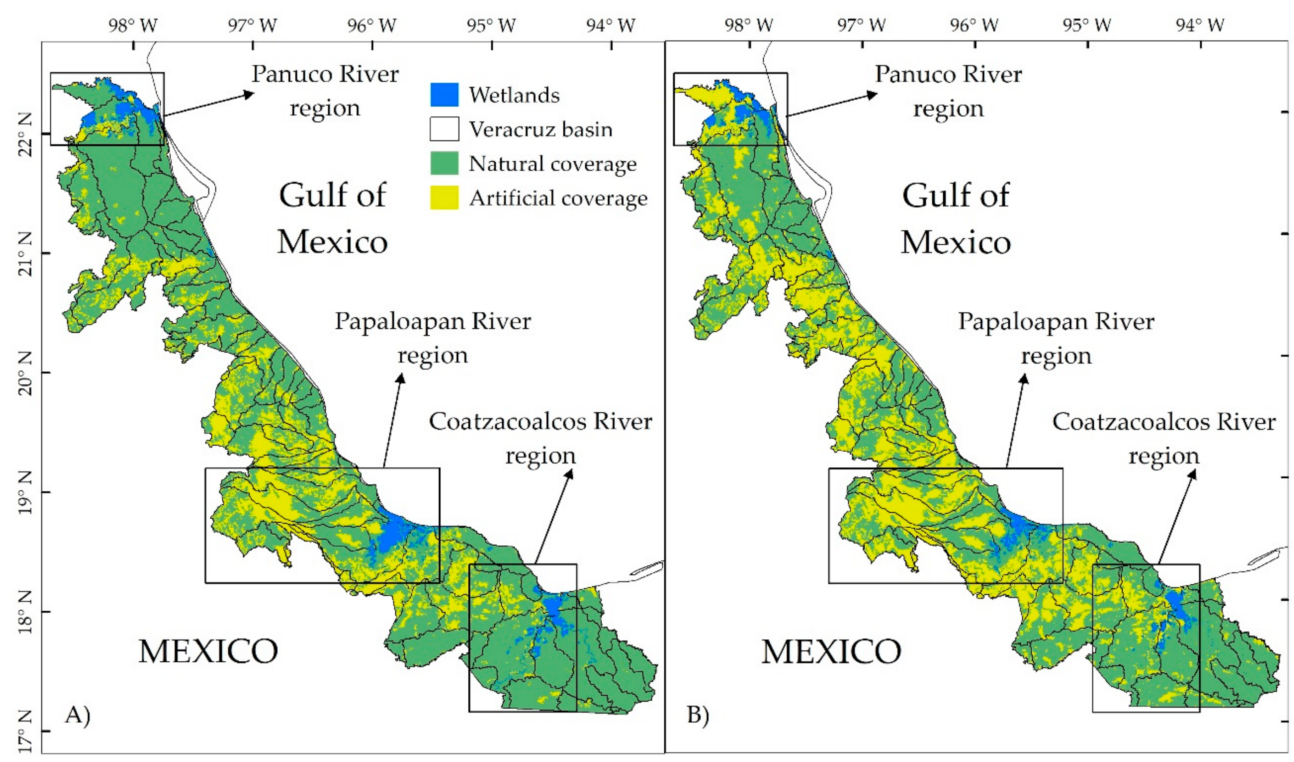

Figure 5. Spatial distribution of natural vegetation and induced land use in Veracruz. (A) 1976 and (B) 2016. Squares correspond to the location of the regions and wetlands under study.

Another factor that contributes to a higher level of vulnerability and risk is related to the condition of wetlands. These ecosystems provide important regulation services to infiltrate water. In the region of interest, wetlands have been reduced (Figure 5) and consequently the natural hydrologic regulation service has diminished significantly. A loss of $32 \%\left(112 \mathrm{~km}^{2}\right), 58 \%\left(307 \mathrm{~km}^{2}\right)$, and $86 \%$ $\left(77.5 \mathrm{~km}^{2}\right)$ in around 40 years for northern, central, and southern wetlands of Veracruz has increased the vulnerability to intense rains [58-60]. Considering the loss of wetlands in hydrological basins, "low", "moderate", and "high" vulnerability levels can be assigned to the northern, central, and southern regions, respectively, which further contributes to the existing vulnerability. 


\subsection{Urban Dynamics}

The rapid demographic growth in the 1970s led to urban expansion and exposure to natural hazards. The lack of planning of these urban settlements made them vulnerable to intense rains and runoffs. A large number of irregular settlements established along rivers and zones of large slopes. Urban services were not always provided to the zones of urban expansion and, consequently, there was a significant level of deterioration of the landscape $[50,66]$ and risk of floods. The demand for more urban space or land for the development of economic activities has continued since then at a more rapid pace than the capacity to solve the problems related to explosive urban growth. An increase in cities in the regions of interest corresponds to a significant change in the area of the urbanization from $0.90 \mathrm{~km}^{2}$ to $44 \mathrm{~km}^{2}$ (northern region), $16 \mathrm{~km}^{2}$ to $165 \mathrm{~km}^{2}$ (central region), and $26 \mathrm{~km}^{2}$ to $192 \mathrm{~km}^{2}$ (southern region), during the period 1970-2016, and their exposure to heavy rains, runoff, and probability of urban flooding also increased.

A spatial analysis of the occurrence of floods indicates that the proximity of the urbanization to the river increases the chances of urban floods. In the northern region, slow urban development took place in the period of analysis with human settlements at "high" proximity with respect to the river, which resulted in 36 flood events during the 1970-2016 period, but with a clear bias to more events in recent years. In the central and southern regions, there have been around 33 and 68 reports in the same period, but more than $50 \%$ have occurred since 2000 . During the analysis period, the north and south regions showed a similar number of urban floods, even when hazardous precipitation events are lower in the northern region of Veracruz. In other words, the vulnerability to intense rains in the Pánuco region seems to be more important in the northern part of the state than in the central-southern part. Although these intense rain events are greater in the Papaloapan and Coatzacoalcos regions, they have shown a lower trend than that observed before 2000, but with an increase in flooding and maximum urban growth.

\subsection{Flood Dynamics: Case Studies}

The hazard characterization in terms of P95 corresponds to a 5\% chance of occurrence of extreme precipitation among the rainy days in a year or a five-year period. These values are part of the risk estimate and are given in terms of $5 \%$ of probability. The vulnerability to such events may be calculated as an index, which is the combination of vulnerability indicators. For the present study, the value of vulnerability has been obtained mainly in terms of land use changes and is given between 0 and 1, after normalization, and it can be interpreted in terms of very low, low, medium, high, and very high. The combination hazard and vulnerability ends up providing a probability (i.e., risk) between $0 \%$ and $100 \%$, which indicates the chance of a disaster (flood) event. The risk index representation in terms of probabilities reflects the non-deterministic nature of the chances of occurrence of an extreme precipitation and flood event, and the uncertainty associated with the characterization of the vulnerability.

One of the common characteristics of the regions under study is their tendency towards increased vulnerabilities, mainly in relation to land use changes that negatively affect the hydrologic properties of the territory. To better represent the dynamics of risk and its components, the estimates of risk are prepared for the 1970 and 2016 period, subdivided in five-year periods that capture the relatively slow evolution of land use changes. The P95 hazard value and the risk index were standardized between 0 and 1 . The vulnerability associated with the loss of natural vegetation is given in terms of percentage of loss since the year 1970. The risk estimate is compared with the number of urban floods for every study region (Figure 6). 


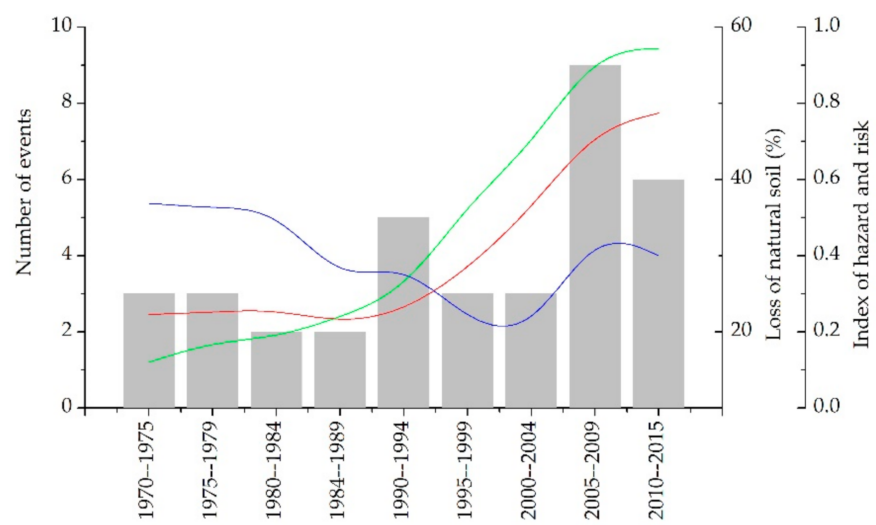

(a)

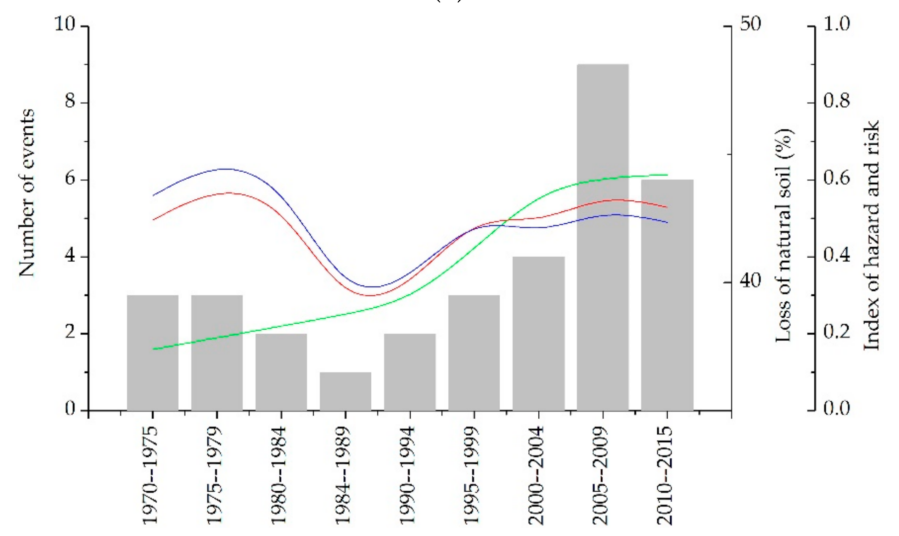

(b)

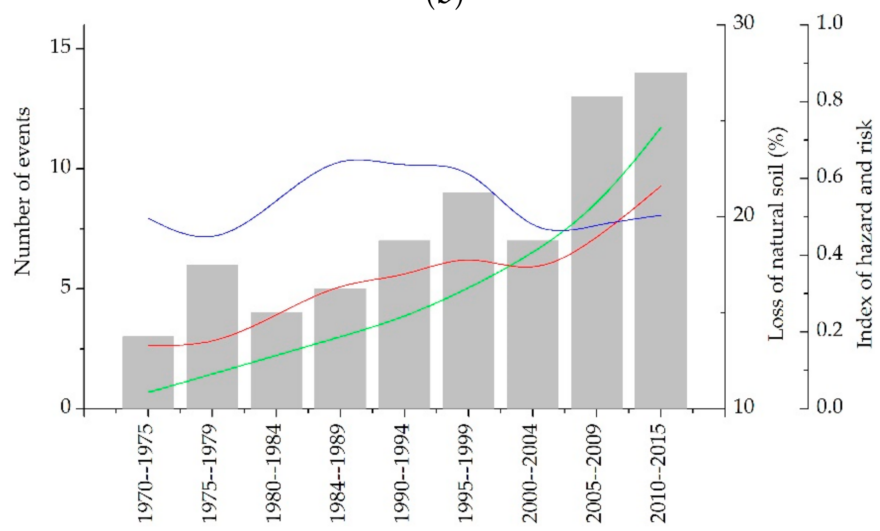

(c)

Figure 6. Hazard index P95 for intense daily precipitation events (blue line) for five years period. Vulnerability associated with the loss of natural vegetation (green line) for the same periods and the corresponding risk index (red line). Number of flood events (gray bar). (a) in the northern region (Panuco), (b) in the central region (Papaloapan) and (c) in the southern region (Coatzacoalcos) in Veracruz state, Mexico.

The risk estimates follow the low-frequency behavior in the number of floods which means that the main factors that increase the number of this type of disasters is mainly land use change. The records of urban flood events show that, in the 1970-1990 period, the number of disasters was relatively low. However, after that date, the number of floods increased, reaching a maximum in the recent decade (Figure 6). It is concluded that the positive trend in the number of floods is related to the loss of ecosystems services of regulation in the basin. The activity of extreme precipitation events determines the high frequency variations, but more vulnerable regions modulate the low-frequency variations of hydrometeorological disasters. 
The P95 value changes in time without showing a defined trend. Even more, in the northern (Panuco) region, the extreme precipitation activity in recent decades appears to diminish even when the frequency of flood events increases. The northern and central regions appear to show reduced extreme precipitation events activity from the mid 1980s to the early 2000s, while the opposite fluctuation is observed in the southern region. It has been suggested that the northern-central precipitation anomalies related to prolonged droughts are usually out of phase with the southern low frequency precipitation anomalies in southern Mexico [67]. In the three regions of the state of Veracruz, the deforestation and land use change (vulnerability) trends exhibited a rapid increase in the 1990s and during the first decade of the twentieth century. This tendency in the basin results in increased runoffs that, in combination with the reduction of the wetlands, generates more water accumulation and floods. The activity in flood events has slightly diminished in recent years in the northern and central parts of Veracruz, in an apparent relation with the reduced rate of land use changes.

The regions of Panuco, Papaloapan, and Coatzacoalcos are on the eastern side of the Sierra Madre of Mexico and consequently the intense rains over the mountains runoff to the coastal zone. The land use changes correspond to the loss of natural vegetation not only in the mountainous regions, but also in the coastal zone, in relation to the degradation of wetlands. A more detailed analysis of the vulnerability should disaggregate the importance of each ecosystems as hydrologic regulators.

These results describe the importance of analyzing the multifactorial vulnerability and risk process to explain the low frequency (longer than interannual) behavior of a disaster activity, such as floods. The negative impact of the intense rains around the world has been frequently related to climate change only, and with the occurrence of more intense rains. This is not always the case. The present study shows that deterioration of ecosystems, such as tropical forest or wetlands, and reduced ecosystem services have severe negative impacts in more exposed urban environments.

The Veracruz region was severely affected by the transition from tropical forests to agricultural and livestock regions. Rapid population growth generated the development of extensive nearby urban areas affected by floods, due to their proximity to the riverbanks. Therefore, a disaster risk reduction strategy must consider the rehabilitation of watersheds to reduce vulnerability through the recovery of ecosystem services.

\section{Conclusions}

The process of transformation of hydrological basins in Mexico, due to the expansion of some economic activities and the rapid growth of cities, generates negative impacts on the original ecosystems affecting, among other things, the infiltration and regulation of runoff generated during intense rains. As a consequence of such degradation of the territory, the number of floods has exponentially increased. The state of Veracruz is an example on how the loss of ecosystem services translates into negative impacts. This region of Mexico has the highest flood record between 1990 and 2015, mostly after the implementation of public policies aimed at expanding the transformation of natural landscapes for productive purposes. However, most of the "official" explanation has frequently been in terms of climate change, i.e., using a naturalistic paradigm, in which this increase in disaster activity is the result of more intense precipitation events. A simple but consistent risk analysis for three regions of the territory between the Sierra Madre and the Gulf of Mexico shows that it is the increase in vulnerability due to the lack of planning in urban growth and the use of the territory which have caused the present level of risk of flooding in the state. This problem is present over most of the Mexican territory, and the official response has been financial compensation for the damage to the infrastructure. The socioeconomic and environmental costs of floods in Mexico has been substantial in recent decades, but unfortunately the tendency to favor economic interests in spite of environmental solutions continues.

The risk index and number of urban floods between 1970 and 1990 exhibits a trend and a very low frequency modulation associated with the vulnerability, in this case, associated with land use changes. On the other hand, the higher frequency variations are more related to the characteristics of 
the natural hazard, in this case, intense rains. The disaster risk reduction strategy should consider the rehabilitation of hydrological basins to recover, at least partially, the ecosystem services that regulate infiltration and runoff. A "natural solution" option may be part of the adaptation to climate change policies in the world. The reforestation and conservation practices may have more benefits than the hydraulic infrastructure solutions. However, it remains necessary to present relatively simple analyses like this to emphasize the main cause of the increased risk and its negative impacts.

As any other disaster, the ones associated with intense rains should be examined in terms of risk, i.e., including the effect of vulnerability. The case of urban floods in the state of Veracruz has been used to show how the deterioration of hydrological basins tends to explain the positive trends in the number of floods, even when the hazard activity (intense rains) remains almost constant or diminishes. This is a clear example of how the naturalistic focus on disasters is inadequate, but at the same time, it provides the opportunity to define disaster risk reduction policies based on ecosystem services.

Author Contributions: E.Z. and V.M. designed the research concept, methodology, and investigation; E.Z. and V.P. performed the data processing and selected the tools for analysis. E.Z., V.M., and V.P. were responsible for editing and review of the manuscript. All authors have read and agreed to the published version of the manuscript.

Funding: This research received financial support from CONACYT by means of the Cátedra Patrimonial to Emanuel Zúñiga. The support from Instituto de Geografía-Universidad Nacional Autónoma de México and LANOT is also appreciated.

Acknowledgments: This study was supported by the National Laboratory of Earth Observation (LANOT 2020) LN-CONACYT-2020-314886, providing computing infrastructure for data processing. We thank Gustavo Vazquez Cruz for his support in scientific computation.

Conflicts of Interest: The authors declare no conflict of interest.

\section{References}

1. Alfieri, L.; Cohen, S.; Galantowicz, J.; Schumann, G.J.-P.; Trigg, M.A.; Zsoter, E.; Prudhomme, C.; Kruczkiewicz, A.; De Perez, E.C.; Flamig, Z.; et al. A Global Network for Operational Flood Risk Reduction. Environ. Sci. Policy 2018, 84, 149-158. [CrossRef]

2. Raikes, J.; Smith, T.F.; Jacobson, C.; Baldwin, C. Pre-Disaster Planning and Preparedness for Floods and Droughts: A Systematic Review. Int. J. Disaster Risk Reduct. 2019, 38, 101207. [CrossRef]

3. Hua, P.; Yang, W.; Qi, X.; Jiang, S.; Xie, J.; Gu, X.; Li, H.; Zhang, J.; Krebs, P. Evaluating the Effect of Urban Flooding Reduction Strategies in Response to Design Rainfall and Low Impact Development. J. Clean. Prod. 2020, 242, 118515. [CrossRef]

4. Islamic Relief Worldwide. Feeling the Heat: The Human Cost of Poor Preparation for Disasters; Islamic Relief Worldwide: London, UK, 2012; Available online: http://lib.riskreductionafrica.org/bitstream/handle/ 123456789/1201/Feeling\%20the\%20heat.The\%20human\%20cost\%20of\%20poor\%20preparation \%20for \% 20disasters.pdf?sequence $=1$ (accessed on 10 May 2020).

5. Höppe, P. Trends in Weather Related Disasters-Consequences for Insurers and Society. Weather Clim. Extrem. 2016, 11, 70-79. [CrossRef]

6. Nkwunonwo, U.; Whitworth, M.; Baily, B. A Review of the Current Status of Flood Modelling for Urban Flood Risk Management in the Developing Countries. Sci. Afr. 2020, 7, e00269. [CrossRef]

7. Istomina, M.N.; Kocharyan, A.G.; Lebedeva, I.P. Floods: Genesis, Socioeconomic and Environmental Impacts. Water Resour. 2005, 32, 349-358. [CrossRef]

8. Schanze, J. Flood Risk Management-A Basic Framework. In Flood Risk Management: Hazards, Vulnerability and Mitigation Measures; Springer: Dordrecht, The Netherlands, 2006; pp. 1-20.

9. Messner, F.; Meyer, V. Flood Damage, Vulnerability and Risk Perception-Challenges for Flood Damage Research. In Flood Risk Management: Hazards, Vulnerability and Mitigation Measures; Springer: Dordrecht, The Netherlands, 2006; pp. 149-167.

10. Du, J.; Cheng, L.; Zhang, Q.; Yang, Y.; Xu, W. Different Flooding Behaviors Due to Varied Urbanization Levels within River Basin: A Case Study from the Xiang River Basin, China. Int. J. Disaster Risk Sci. 2018, 10, 89-102. [CrossRef] 
11. Rubinato, M.; Nichols, A.; Peng, Y.; Zhang, J.-M.; Lashford, C.; Cai, Y.-P.; Lin, P.-Z.; Tait, S. Urban and River Flooding: Comparison of Flood Risk Management Approaches in the UK and China and an Assessment of Future Knowledge Needs. Water Sci. Eng. 2019, 12, 274-283. [CrossRef]

12. Wu, H.; Kimball, J.S.; Zhou, N.; Alfieri, L.; Luo, L.; Du, J.; Huang, Z. Evaluation of Real-Time Global Flood Modeling with Satellite Surface Inundation Observations from SMAP. Remote. Sens. Environ. 2019, 233, 111360. [CrossRef]

13. Dottori, F.; Szewczyk, W.; Ciscar, J.-C.; Zhao, F.; Alfieri, L.; Hirabayashi, Y.; Bianchi, A.; Mongelli, I.; Frieler, K.; Betts, R.A.; et al. Increased Human and Economic Losses From River Flooding with Anthropogenic Warming. Nat. Clim. Chang. 2018, 8, 781-786. [CrossRef]

14. Price, R.K.; Vojinovic, Z. Urban Flood Disaster Management. Urban Water J. 2008, 5, 259-276. [CrossRef]

15. Salack, S.; Saley, I.A.; Lawson, N.Z.; Zabré, I.; Daku, E.K. Scales for Rating Heavy Rainfall Events in the West African Sahel. Weather. Clim. Extrem. 2018, 21, 36-42. [CrossRef]

16. Jiang, Y.; Zevenbergen, C.; Ma, Y. Urban Pluvial Flooding and Stormwater Management: A Contemporary Review of China's Challenges and "Sponge Cities" Strategy. Environ. Sci. Policy 2018, 80, 132-143. [CrossRef]

17. Bonasia, R.; Lucatello, S. Linking Flood Susceptibility Mapping and Governance in Mexico for Flood Mitigation: A Participatory Approach Model. Atmosphere 2019, 10, 424. [CrossRef]

18. Ke, Q.; Tian, X.; Bricker, J.; Tian, Z.; Guan, G.; Cai, H.; Huang, X.; Yang, H.; Liu, J. Urban Pluvial Flooding Prediction by Machine Learning Approaches-A Case Study of Shenzhen City, China. Adv. Water Resour. 2020, 145, 103719. [CrossRef]

19. Akter, A.; Tanim, A.H.; Islam, M.K. Possibilities of Urban Flood Reduction Through Distributed-Scale Rainwater Harvesting. Water Sci. Eng. 2020, 13, 95-105. [CrossRef]

20. Trenberth, K.E. Changes in Precipitation With Climate Change. Clim. Res. 2011, 47, 123-138. [CrossRef]

21. Hirabayashi, Y.; Mahendran, R.; Koirala, S.; Konoshima, L.; Yamazaki, D.; Watanabe, S.; Kim, H.; Kanae, S. Global Flood Risk Under Climate Change. Nat. Clim. Chang. 2013, 3, 816-821. [CrossRef]

22. UNDRO, M.N.D. Phenomena, Effects, and Options-A Manual for Policy Makers and Planners; Office of the United Nations Disaster Relief Co-ordinator: Geneva, Switzerland; New York, NY, USA, 1991; Available online: http://cidbimena.desastres.hn/pdf/eng/doc1028/doc1028.htm (accessed on 26 May 2020).

23. Plate, E.J. Flood Risk and Flood Management. J. Hydrol. 2002, 267, 2-11. [CrossRef]

24. Zúñiga, E.; Magaña, V. Vulnerability and Risk to Intense Rainfall in Mexico: The Effect to Land Use Cover Change. Investig. Geográficas 2017, 95, 1-18. [CrossRef]

25. Talchabhadel, R.; Karki, R.; Thapa, B.R.; Maharjan, M.; Parajuli, B. Spatio-Temporal Variability of Extreme Precipitation in Nepal. Int. J. Clim. 2018, 38, 4296-4313. [CrossRef]

26. Pfister, L.; Kwadijk, J.C.J.; Musy, A.; Bronstert, A.; Hoffmann, L. Climate Change, Land Use Change and Runoff Prediction in the Rhine-Meuse Basins. River Res. Appl. 2004, 20, 229-241. [CrossRef]

27. Al-Ruzouq, R.; Yilmaz, A.G.; Shanableh, A.; Boharoun, Z.A.; Khalil, M.A.; Alam Imteaz, M. Spatio-Temporal Analysis of Urban Growth and Its Impact on Floods in Ajman City, UAE. Environ. Monit. Assess. 2019, 191, 656. [CrossRef] [PubMed]

28. Sriwongsitanon, N.; Taesombat, W. Effects of Land Cover on Runoff Coefficient. J. Hydrol. 2011, 410, $226-238$. [CrossRef]

29. Erena, S.H.; Worku, H. Dynamics of Land Use Land Cover and Resulting Surface Runoff Management for Environmental Flood Hazard Mitigation: The Case of Dire Daw City, Ethiopia. J. Hydrol. Reg. Stud. 2019, 22, 100598. [CrossRef]

30. Thieken, A.H.; Cammerer, H.; Dobler, C.; Lammel, J.; Schöberl, F. Estimating Changes in Flood Risks and Benefits of Non-Structural Adaptation Strategies-A Case Study From Tyrol, Austria. Mitig. Adapt. Strat. Glob. Chang. 2014, 21, 343-376. [CrossRef] [PubMed]

31. Paquier, A.; Mignot, E.; Bazin, P.-H. From Hydraulic Modelling to Urban Flood Risk. Procedia Eng. 2015, 115, 37-44. [CrossRef]

32. Ali, M.; Hadi, S.; Sulistyantara, B. Study on Land Cover Change of Ciliwung Downstream Watershed with Spatial Dynamic Approach. Procedia-Soc. Behav. Sci. 2016, 227, 52-59. [CrossRef]

33. Yang, W.; Long, D.; Bai, P. Impacts of Future Land Cover and Climate Changes on Runoff in the Mostly Afforested River Basin in North China. J. Hydrol. 2019, 570, 201-219. [CrossRef] 
34. Satya, B.A.; Shashi, M.; Pratap, D. Effect of Temporal-Based Land Use-Land Cover Change Pattern on Rainfall Runoff. In Amplications of Geomatics in Civil Engineering; Springer Science and Business Media LLC: Singapore, 2019; pp. 175-182.

35. DeFries, R.S.; Eshleman, K.N. Land-Use Change and Hydrologic Processes: A Major Focus for the Future. Hydrol. Process. 2004, 18, 2183-2186. [CrossRef]

36. Nur, I.; Shrestha, K.K. An Integrative Perspective on Community Vulnerability to Flooding in Cities of Developing Countries. Procedia Eng. 2017, 198, 958-967. [CrossRef]

37. Flores, A.P.; Giordano, L.; Ruggerio, C.A. A Basin-Level Analysis of Flood Risk in Urban and Periurban Areas: A Case Study in the Metropolitan Region of Buenos Aires, Argentina. Heliyon 2020, 6, e04517. [CrossRef] [PubMed]

38. Wu, J.; Wu, Z.-Y.; Lin, H.-J.; Ji, H.-P.; Liu, M. Hydrological Response to Climate Change and Human Activities: A Case Study of Taihu Basin, China. Water Sci. Eng. 2020, 13, 83-94. [CrossRef]

39. Wang, Y.; Xie, X.; Liang, S.; Zhu, B.; Yao, Y.; Meng, S.; Lu, C. Quantifying the Response of Potential Flooding Risk to Urban Growth in Beijing. Sci. Total Environ. 2020, 705, 135868. [CrossRef] [PubMed]

40. UN. United Nations Population Division World Urbanization Prospects: The 2018 Re-Vision. 2018. Available online: https://population.un.org/wup/ (accessed on 9 May 2020).

41. Zhou, F.; Xu, Y.; Chen, Y.; Xu, C.-Y.; Gao, Y.; Du, J. Hydrological Response to Urbanization at Different Spatio-Temporal Scales Simulated by Coupling of CLUE-S and the SWAT Model in the Yangtze River Delta Region. J. Hydrol. 2013, 485, 113-125. [CrossRef]

42. Rojas, O.; Mardones, M.; Rojas, C.; Martínez, C.; Flores, L. Urban Growth and Flood Disasters in the Coastal River Basin of South-Central Chile (1943-2011). Sustainability 2017, 9, 195. [CrossRef]

43. Qi, Z.-F.; Ye, X.-Y.; Zhang, H.; Yu, Z.-L. Land Fragmentation and Variation of Ecosystem Services in the Context of Rapid Urbanization: The Case of Taizhou City, China. Stoch. Environ. Res. Risk Assess. 2013, 28, 843-855. [CrossRef]

44. Xian, G.; Crane, M.; Su, J. An Analysis of Urban Development and Its Environmental Impact on the Tampa Bay Watershed. J. Environ. Manag. 2007, 85, 965-976. [CrossRef]

45. Aguilar-Barajas, I.; Sisto, N.P.; Ramirez, A.I.; Magaña-Rueda, V. Building Urban Resilience and Knowledge Co-Production in the Face of Weather Hazards: Flash Floods in the Monterrey Metropolitan Area (Mexico). Environ. Sci. Policy 2019, 99, 37-47. [CrossRef]

46. Areu-Rangel, O.S.; Gómez, L.C.; Bonasia, R.; Espinosa-Echavarria, V.J. Impact of Urban Growth and Changes in Land Use on River Flood Hazard in Villahermosa, Tabasco (Mexico). Water 2019, 11, 304. [CrossRef]

47. Wan, R.; Yang, G. Influence of Land Use/Cover Change on Storm Runoff-A Case Study of Xitiaoxi River Basin in Upstream of Taihu Lake Watershed. Chin. Geogr. Sci. 2007, 17, 349-356. [CrossRef]

48. Dinka, M.O.; Klik, A. Effect of Land Use-Land Cover Change on the Regimes of Surface Runoff-The Case of Lake Basaka Catchment (Ethiopia). Environ. Monit. Assess. 2019, 191, 278. [CrossRef] [PubMed]

49. Poku-Boansi, M.; Amoako, C.; Owusu-Ansah, J.K.; Cobbinah, P.B. What the State Does but Fails: Exploring Smart Options for Urban Flood Risk Management in Informal Accra, Ghana. City Environ. Interact. 2020, 5, 100038. [CrossRef]

50. Mas, J.F.; Velázquez, A.; Couturier, S. LA Evaluación de Los Cambios de Cobertura/Uso Del Suelo en la República Mexicana. Investigación Ambiental Ciencia Y Política Pública. 2009. Available online: http://www.ccmss.org.mx/wp-content/uploads/2014/10/La_evaluacion_de_los_cambios_de_coberturauso_de_suelo_en_la_Republica_Mexicana.pdf (accessed on 25 May 2020).

51. Valdes-Manzanilla, A. Effect of Climatic Oscillations on Flood Occurrence on Papaloapan River, México, during the 1550-2000 Period. Nat. Hazards 2018, 94, 167-180. [CrossRef]

52. Dykstra, S.L.; Dzwonkowski, B. The Intensifying Frequency of Coastal Flooding, Northeast Gulf of Mexico Watersheds. AGUFM 2019, H53I-1876. Available online: https:/ui.adsabs.harvard.edu/abs/2019AGUFM. H53I1876D (accessed on 28 May 2020).

53. CENAPRED. Impacto Socioeconómico de Los Principales Desastres Ocurridos En La República Mexicana; Serie Impacto Socioeconómico de Los Desastres En México; Secretaría de Gobernación-CENAPRED: Ciudad de México, Mexico, 2017; Volume 1-15. Available online: https://datos.gob.mx/busca/dataset/impactosocioeconomico-de-desastres-de-2000-a-2015 (accessed on 1 January 2020).

54. DesInventar. Sistema de Inventario de Desastres. Available online: https://online.desinventar.org/ (accessed on 30 May 2020). 
55. FONDEN. Declaratoria de Emergencia de Desastres. Available online: https://datos.gob.mx/busca/dataset/ centro-nacional-de-prevencion-de-desastres/resource/fa17739f-83f2-424a-ac48-fea7c721ed31 (accessed on 15 January 2020).

56. Haer, T.; Botzen, W.; Zavala-Hidalgo, J.; Cusell, C.; Ward, P.J. Economic Evaluation of Climate Risk Adaptation Strategies: Cost-Benefit Analysis of Flood Protection in Tabasco, Mexico. Atmósfera 2017, 30, 101-120. [CrossRef]

57. Armenta-Montero, S.; Lopez Acosta, J.C.; Rodríguez-Luna, E.; Ellis, E.; del Amo Rodríguez, S.; Gómez-Pompa, A.; Mac Swiney González, M.C.; Niembro-Rocas, A.; Sanchez, O.; Vázquez-Torres, M.; et al. La Restauración Ecológica Como Estrategia Para la Reducción Del Riesgo de Desastre Ante Inundaciones: Estudio de Caso de la Cuenca Del Río Coatzacoalcos In Las Inundaciones de 2010 en Veracruz. Memoria Social y Medio Físico; Gobierno del Estado de Veracruz: Veracruz, Mexico, 2012; pp. 216-258. Available online: http://libros.uv.mx/index.php/UV/catalog/book/FC189 (accessed on 18 June 2020).

58. Vázquez-González, C.; Moreno-Casasola, P.; Peláez, L.A.P.; Monroy, R.; Espejel, I.; Peralta, L.A. The Value of Coastal Wetland Flood Prevention Lost to Urbanization on the Coastal Plain of the Gulf of Mexico: An Analysis of Flood Damage by Hurricane Impacts. Int. J. Disaster Risk Reduct. 2019, 37, 101180. [CrossRef]

59. Pérez-Maqueo, O.; Martinez, M.L.; Sánchez-Barradas, F.C.; Kolb, M. Assessing Nature-Based Coastal Protection against Disasters Derived from Extreme Hydrometeorological Events in Mexico. Sustainability 2018, 10, 1317. [CrossRef]

60. Magaña, V.; Gómez, L.; Neri, C.; Landa, R.; León, C.; Ávila, B. Medidas de Adaptación Al Cambio Climático en Humedales Del Golfo de México; INE: Mexico City, Mexico; SEMARNAT: Mexico City, Mexico; UNAM: Mexico City, Mexico; BM: Mexico City, Mexico; UAM: Mexico City, Mexico, 2011; p. 90. Available online: http://awsassets.panda.org/downloads/librohumedales_baja_julio2011.pdf (accessed on 14 June 2020).

61. SMN. Información Estadística Climatológica. Available online: https://smn.conagua.gob.mx/es/climatologia/ informacion-climatologica/informacion-estadistica-climatologica (accessed on 16 May 2020).

62. INEGI. Conjunto de Datos Vectoriales de uso de Suelo y Vegetación. Available online: https://www.inegi.org. mx/temas/usosuelo/ (accessed on 5 May 2020).

63. Magaña, V.; Méndez, J.M.; Morales, R.; Millán, C. Consecuencias Presentes Y Futuras de la Variabilidad Y El Cambio Climático en México. In Cambio Climático: Una Visión Desde México; Instituto Nacional de Ecología: Delegación Coyoacán, Mexico, 2004; pp. 203-213. Available online: http://cambioclimatico.gob.mx: 8080/xmlui/handle/publicaciones/129 (accessed on 25 June 2020).

64. Caetano, E.; Kusunoki, S.; Pérez, E.P.; Magaña, V. Cold Surge Activity Over the Gulf of Mexico in a Warmer Climate 1. Front. Earth Sci. 2014, 2. [CrossRef]

65. Neri, C.; Magaña, V. Estimation of Vulnerability and Risk to Meteorological Drought in Mexico. Weather. Clim. Soc. 2016, 8, 95-110. [CrossRef]

66. Mas, J.-F.; Velázquez, A.; Díaz-Gallegos, J.R.; Mayorga-Saucedo, R.; Alcántara, C.; Bocco, G.; Castro, R.; Fernández, T.; Pérez-Vega, A. Assessing Land Use/Cover Changes: A Nationwide Multidate Spatial Database for Mexico. Int. J. Appl. Earth Obs. Geoinf. 2004, 5, 249-261. [CrossRef]

67. Méndez, M.; Magaña, V. Regional Aspects of Prolonged Meteorological Droughts over Mexico and Central America. J. Clim. 2010, 23, 1175-1188. [CrossRef]

(C) 2020 by the authors. Licensee MDPI, Basel, Switzerland. This article is an open access article distributed under the terms and conditions of the Creative Commons Attribution (CC BY) license (http://creativecommons.org/licenses/by/4.0/). 